ISSN: 1410-8917

Jurnal Kimia

Sains \&

Aplikasi
Jurnal Kimia Sains dan Aplikasi Journal of Scientific and Applied Chemistry

Journal homepage: http://ejournal.undip.ac.id/index.php/ksa

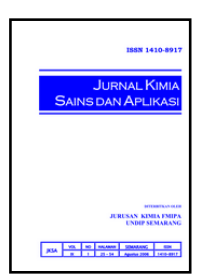

\title{
Isolasi dan Uji Antibakteri Senyawa Terpenoid Ekstrak N-Heksana Rimpang Lengkuas Merah (Alpinia purpurata)
}

\author{
Fajar Budi Laksono ${ }^{a}$, Enny Fachriyah ${ }^{a^{*}}$, Dewi Kusrini ${ }^{\mathrm{b}}$ \\ a Organic Chemistry Laboratory, Chemistry Department, Faculty of Sciences and Mathematics, Diponegoro University, Jalan Prof. \\ Soedarto, Tembalang, Semarang \\ * Corresponding author: enny.fachriyah@live.undip.ac.id
}

Article Info

Keywords:

Alpinia purpurata, terpenoid,

kromatography, antibactery

\section{Abstract}

The red galangal plant (Alpinia purpurata) is a medicinal plant belonging to the Zingiberacea family and is widely used as a medicinal plant for throat, rheumatic, and headache diseases. The objective of this study was to isolate terpenoids from red galangal rhizome and to analyze the isolation result using FTIR and GC-MS spectrophotometer and to test antibacterial activity of terpenoid compound by determining minimum inhibitory concentration by disc diffusion method. This research was started by maseration of red galangal powder with ethanol solvent. The ethanol extract was then partitioned with $n$-hexane solvent. After that, the $n$-hexane extract was analyzed using TLC and column chromatography. A positive fraction of terpenoids was then performed by preperative TLC and purity test. From the results of FTIR and GC-MS analysis of terpenoid isolates, it was concluded that terpenoid compounds obtained from the process of isolation of red galangal rhizomes were compounds 3,7,11trimethyl-1,6,10-dodekatrien-3-ol or nerolidol. The terpenoid isolates were then tested for antibacterial activity at concentrations of $5 \%, 1 \%$, and $0.5 \%$ and did not provide antibacterial activity against Escherichia coli and Salmonella typhi bacteria.

\section{Abstrak}

Tanaman lengkuas merah (Alpinia purpurata) merupakan tanaman obat yang termasuk dalam famili Zingiberacea dan banyak digunakan sebagai tanaman obat untuk penyakit tenggorokan, rematik, dan sakit kepala. Penelitian ini bertujuan untuk mengisolasi terpenoid dari rimpang lengkuas merah dan menganalisis hasil isolasinya menggunakan spektrofotometer FTIR dan GC-MS serta menguji aktivitas antibakteri senyawa terpenoid dengan menentukan konsentrasi hambat minimum dengan metode difusi cakram. Penelitian ini dimulai dengan cara maserasi serbuk rimpang lengkuas merah dengan pelarut etanol. Ekstrak etanol kemudian dipartisi dengan pelarut $\mathrm{n}$ heksana. Setelah itu, ekstrak n-heksana dianalisis mengguanak KLT dan Kromatografi kolom. Fraksi yang positif terhadap terpenoid kemudian dilakukan KLT preperatif dan uji kemurnian. Dari hasil analisis FTIR dan GC-MS dari isolat terpenoid, disimpulkan bahwa senyawa terpenoid yang diperoleh dari proses isolasi rimpang lengkuas merah adalah senyawa 3,7,11-trimetil-1,6,10-dodekatrien-3-ol atau nerolidol. Isolat terpenoid kemudian diuji aktivitas antibakteri pada konsentrasi 5\%, 1\%, dan 0,5\% dan tidak memberikan aktivitas antibakteri terhadap bakteri Eschericia coli dan Salmonella typhi.

\section{Pendahuluan}

Tanaman lengkuas merah (Alpinia purpurata) merupakan tanaman obat yang termasuk dalam famili
Zingiberacea [1]. Rimpang lengkuas merah secara luas digunakan pada pengobatan penyakit perut, kudis, panu, dan menghilangkan bau mulut [2]. Rimpang 
lengkuas merah juga dianggap memiliki khasiat sebagai anti tumor atau anti kanker terutama tumor di bagian mulut dan lambung [3]. Selain itu rimpang lengkuas merah juga memiliki aktivitas antibakteri sehingga rimpang tanaman ini dapat menyembuhkan beberapa penyakit yang disebabkan oleh bakteri.

Ekstrak etanol dari rimpang lengkuas merah mengandung senyawa-senyawa aktif diantaranya adalah flavonoid, terpenoid, saponin dan tannin [4]. Salah satu senyawa aktif yang berpotensi menjadi agen anti bakteri adalah terpenoid [5]. Terpenoid adalah senyawa dengan kerangka isoprena yang telah mengalami modifikasi. Potensi terpenoid dalam lengkuas merah masih belum banyak dimanfaatkan sehingga perlu adanya penelitian yang lebih guna menelusuri pemanfaatan senyawa terpenoid dalam rimpang lengkuas merah. Dalam penelitian ini akan diisolasi senyawa terpenoid dengan pelarut $n$-heksana dan diuji aktivitas antibakteri terhadap Eschericia coli dan Salmonella typhi.

Sebelumnya telah dilakukan penelitian tentang rimpang lengkuas merah yakni uji fitokimia, uji larvasida, serta uji aktivitas antibakteri minyak atsiri rimpang lengkuas merah [6], uji aktivitas ekstrak lengkuas merah terhadap bakteri dan jamur dan uji aktivitas antioksidan secara in-vitro dan uji fitokimia dari ekstrak etanol rimpang lengkuas merah, tetapi belum ada penelitian mengenai isolasi dan uji aktivitas antibakteri senyawa terpenoid dari ekstrak n-heksana dari rimpang lengkuas merah dengan bakteri uji Eschericia coli dan Salmonella typhi [4].

Penelitian ini bertujuan memperoleh terpenoid dari rimpang lengkuas merah dan menganalisis senyawa tersebut menggunakan spektrofotometer FTIR dan GCMS serta menguji aktivitas antibakteri isolat terpenoid dengan metode difusi cakram.

\section{Metode Penelitian}

\section{Alat dan Bahan}

Alat gelas standar penelitian, corong pemisah, botol vial, pipet mikro, satu set Kromatografi Lapis Tipis (KLT), satu set kromatografi kolom, plat kromatografi preparatif, alat pembuat kromatografi preparatif, seperangkat rotary evaporator, neraca analitis, seperangkat spektrofotometer Fourier Transform Inframerah, seperangkat alat GC-MS, inkubator, cawan petri, jarum ose, autoklaf, sentrifuge, shaker. Sampel lengkuas merah, etanol (teknis), n-heksana (pa), nheksana (teknis), etil asetat (pa), kloroform (pa), kloroform (teknis), aquades, Nutrien Agar (NA), pepton, bakteri Eschercia coli, Salmonella typhi, pereaksi Liberman-Burchard (anhidrida asam asetat dan asam sulfat pekat 3:1), DMSO, serbuk silika gel GF254, Silika gel $60 \mathrm{G}$, plat KLT silikia gel GF254. Semua reagen pro analys menggunakan reagen dari merck.

\section{Preparasi Simplisia}

Sebanyak $5 \mathrm{~kg}$ rimpang lengkuas merah dibersihkan kemudian dikeringkan dengan cara diangin-anginkan. Sampel yang telah kering selanjutnya dihaluskan dengan menggunakann penggiling.

\section{Pengambilan Fraksi n-Heksana Rimpang Lengkuas Merah}

Serbuk rimpang lengkuas merah sebanyak 0,6 kg dimaserasi dengan etanol. Pelarut diganti setiap 24 jam sekali selama 1 minggu. Selanjutnya ekstrak tersebut dipekatkan dengan menggunakan rotary eveporator. Setelah didapatkan ekstrak pekat etanol, dilakukan partisi dengan cara menambahkan n-heksana dengan perbandingan 1 : 1 . Partisi dilakukan sampai warna fraksi $\mathrm{n}$-heksana tetap. Selanjutnya fraksi $\mathrm{n}$ heksana dilakukan pemekatan menggunakan rotary evaporator sehingga didapatkan ekstrak kental n-heksana.

\section{Pemisahan dengan Kromatografi Kolom}

Sebelum dilakukan kromatografi kolom terlebih dahulu dilakukan penentuan eluen terbaik menggunakan KLT dengan fasa diam Silika gel $60 \mathrm{GF}_{254}$ dan fasa gerak campuran eluen dengan perbandingan tertentu. Setelah didapatkan eluen yang sesuai selanjutnya dilakukan kromatografi kolom dengan eluen tersebut. Silika gel $60 \mathrm{G}$ sebanyak 120 gram dibuburkan dengan campuran eluen kemudian dimasukkan ke dalam kolom dan didiamkan selama 24 jam.

Selanjutnya sebanyak 3 gram fraksi $n$-heksana rimpang lengkuas merah dimasukkan ke dalam kolom. Pemisahan dengan kromatografi kolom dilakukan dengan cara mengatur aliran eluen yang ditampung dalam setiap botol vial, aliran eluen dibuat 8 menit / 15 $\mathrm{mL}$ setiap vialnya. Selanjutnya vial hasil kolom dilakukan KLT untuk pengelompokan fraksi berdasarkan pola noda yang sama kemudian disatukan menjadi fraksi besar.

\section{Identifikasi Terpenoid}

Fraksi-fraksi besar yang didapat kemudian dilakukan KLT dan disemprot menggunakan pereaksi Libermann-Burchard. Selanjutnya KLT tersebut dimasukkan kedalam oven dengan suhu $110^{\circ} \mathrm{C}$ selama 5 menit. Noda dari KLT tersebut selanjutnya dilihat pada lampu UV $365 \mathrm{~nm}$.

\section{Pemisahan dengan Kromatografi Preparatif}

Kromatografi preparatif dilakukan terhadap fraksi yang positif terpenoid untuk mendapatkan isolat terpenoid murni. Sebelumnya dilakukan KLT untuk menentukan eluen terbaik. Kromatografi preparatif dilakukan dengan plat silika gel $\mathrm{GF}_{254}$ ukuran $20 \mathrm{~cm} \mathrm{x} 5$ cm dengan ketebalan $0,2 \mathrm{~cm}$. Setelah fraksi positif terpenoid dielusi, dilakukan pengerokan pita-pita dan selanjutnya direndam menggunakan $\mathrm{n}$-heksana pro analis yang melarutkan isolat terpenoid.

\section{Uji Kemurnian}

Uji kemurnian dilakukan menggunakan KLT dengan fase gerak berbagai campuran eluen yaitu kloroform : n-heksana ( $7: 3)$, etil asetat : n-heksana (5 : 3), dan kloroform : n-heksana (1:1). Jika hasil KLT 
menunjukkan 1 noda maka isolat terpenoid tersebut dianggap murni.

\section{Analisis FTIR dan GC-MS serta Uji Aktivitas Antibakteri}

Analisis FTIR digunakan untuk menentukan gugus fungsi dan Kromatografi Gas untuk mengetahui tingkat kemurnian serta menggunakan Spektroskopi Massa untuk mengetahui berat molekul dan pola fragmentasi dari senyawa tersebut.

Uji aktivitas antibakteri terhadap isolat terpenoid menggunakan metode difusi cakram dengan konsentrasi $5 \%, 1 \%$, dan $0,5 \%$. Nutrien agar yang telah dibuat kemudian disterilisasi dalam autoklaf. Nutrien agar yang telah steril diberi supensi bakteri dan diratakan dengan menggunakan jarum ose. Cakram kertas dicelupkan ke dalam isolat terpenoid rimpang lengkuas merah diletakan pada permukaan media nutrien agar yang telah diinokulasikan bakteri dan diinkubasi selama 24 jam pada suhu $37^{\circ} \mathrm{C}$ [7].

\section{Hasil Dan Pembahasan}

\section{Preparasi Sampel}

Hasil proses pengeringan sampel dari $5 \mathrm{~kg}$ rimpang lengkuas merah basah didapat bobot kering sampel menjadi 0,6 kg. Dari hasil pengeringan tersebut didapat warna dari rimpang lengkuas merah menjadi lebih kecoklatan dan setelah digiling didapat serbuk rimpang lengkuas merah 0,5 kg dengan warna coklat kemerahan.

Pengambilan Fraksi n-Heksana Rimpang Lengkuas Merah

Maserasi dengan etanol berfungsi untuk mengisolasi metabolit sekunder yang terdapat dalam rimpang lengkuas merah. Ekstrak etanol hasil maserasi didapatkan cairan berwarna merah kecoklatan dan selanjutnya ekstrak tersebut dipekatkan dengan menggunakan rotary eveporator sehingga didapatkan 50 mL ekstrak etanol rimpang lengkuas merah.

Setelah didapatkan ekstrak etanol dari lengkuas merah selanjutnya dilakukan partisi dengan menggunakan n-heksana. Terpenoid merupakan senyawa non polar sehingga dapat larut dalam nheksana dan senyawa lain yang bersifat lebih polar akan tetap di dalam ekstrak etanol. Cairan yang didapat dari hasil partisi menggunakan $\mathrm{n}$-heksana berwarna kuning terang. Setelah fraksi tersebut dipekatkan diperoleh sebanyak 4 gram fraksi n-heksana berwarna coklat kemerahan.

\section{Pemisahan dengan Kromatografi Kolom}

Dari hasil KLT didapatkan bahwa eluen terbaik untuk pemisahan terpenoud adalah kloroform : nheksana (10 : 9). Perbandingan eluen tersebut menghasilkan pemisahan noda yang paling maksimal yaitu didapatkan 7 noda dengan Rf masing-masing noda antara $0,2-0,8$. Eluen tersebut digunakan untuk kromatografi kolom gravitasi.

Dari hasil kromatografi kolom diperoleh 220 vial masing-masing vial dilakukan KLT untuk pengelompokan fraksi besar seperti ditunjukkan pada tabel 1.

Tabel 1: Hasil pengelompokkan fraksi vial-vial hasil kromatografi kolom

\begin{tabular}{ccc}
\hline Fraksi & Vial & Warna \\
\hline A & $5-19$ & Jernih \\
B & $20-55$ & Jernih \\
C & $56-98$ & Jernih \\
D & $99-143$ & Jernih \\
E & $144-220$ & Kekuningan \\
\hline
\end{tabular}

Identifikasi Terpenoid

Identifikasi terpenoid dilakukan dengan uji Liberrman Burchard terhadap 5 fraksi (A, B, C, D, E) untuk mengetahui adanya terpenoid. Senyawa terpenoid apabila disemprot dengan reagen Liberrman Burchard akan tampak noda berwarna ungu apabila dilihat di bawah UV $365 \mathrm{~nm}$. Hasil identifikasi terpenoid ditunjukkan seperti gambar 1 .

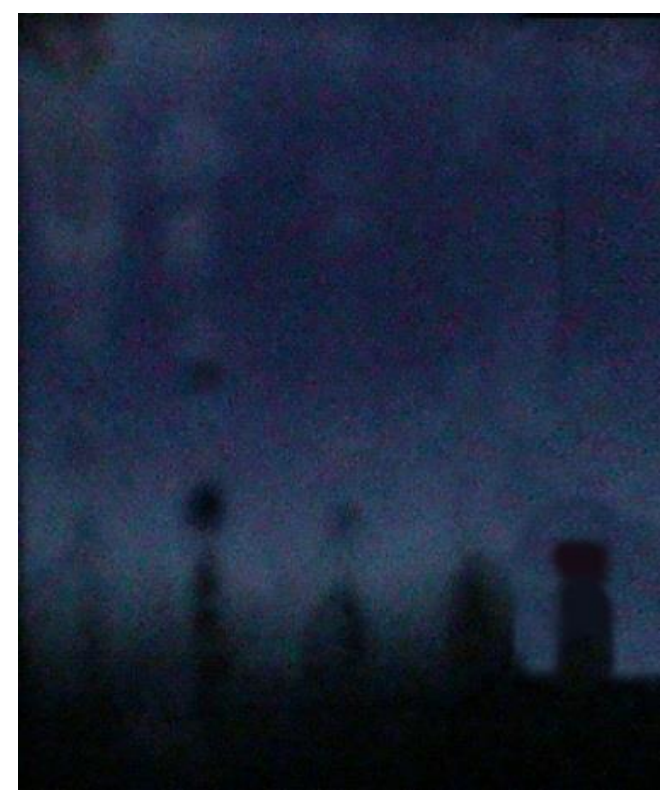

Gambar 6. Hasil Kromatografi Lapis Tipis Fraksi A - E dengan eluen Kloroform:n-hexane 10:9

Pemisahan dengan Kromatografi Preparatif

Pada uji terpenoid dari fraksi E dengan KLT menggunakan eluen kloroform : n-heksana (10:9) didapatkan noda terpenoid berwarna ungu berdekatan dengan noda lain sehingga apabila tidak dipisahkan, maka noda selain senyawa target yang akan diambil akan terbawa dan tidak dihasilkan isolat murni. Setelah dilakukan KLT kembali dengan eluen kloroform : nheksana (7:3) diperoleh hasil pemisahan yang baik antara target terpenoid dengan senyawa lain. Setelah mendapatkan eluen terbaik dilakukan isolasi terpenoid dengan mengerok silika gel pada daerah pita yang positif terpenoid. Hasil kromatografi preparatif ditunjukkan oleh gambar 2. 


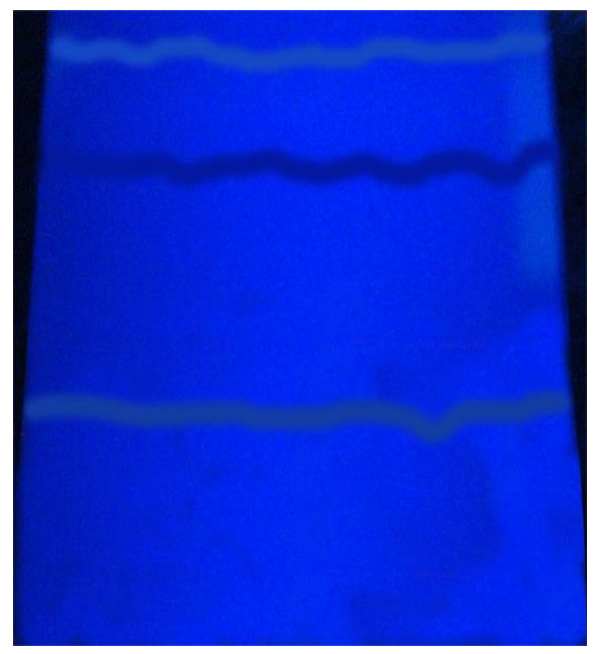

Gambar 2. Kromatografi Preparatif Fraksi E dengan eluen kloroform : n-heksana $7: 3$ di bawah lampu UV $365 \mathrm{~nm}$

Silika hasil pengerokan kromatografi preparatif selanjutnya dilakukan perendaman menggunakan nheksana sehingga didapatkan cairan berwana kekuningan. Setelah didapat isolat terpenoid selanjutnya dilakukan penentuan tingkat kemurnian isolat terpenoid melalui uji kemurnian.

\section{Uji Kemurnian}

Uji kemurnian isolat terpenoid dilakukan dengan menggunakan metode KLT dengan berbagai eluen. Eluen yang dipakai adalah kloroform : n-heksana ( $7: 3$, etil asetat : n-heksana (5:3), dan kloroform : nheksana $(1: 1)$. Uji kemurnian isolat terpenoid dengan KLT berbagai eluen ditunjukkan seperti pada gambar 3.

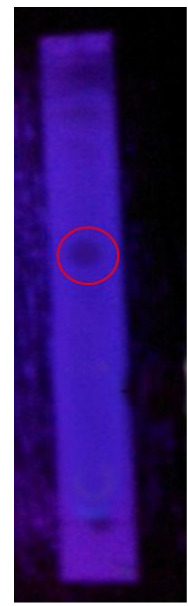

(a)

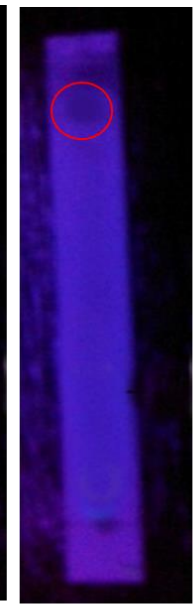

(b)

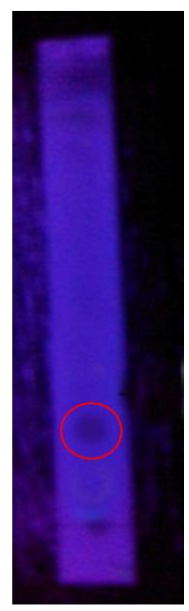

(c)
Gambar 3. KLT isolat terpenoid (a) Eluen kloroform : n-heksana (7:3); (b) Etil asetat : n-heksana ( $5: 3)$; (c)

Kloroform : n-heksana $(1: 1)$

Hasil KLT pada uji kemurnian isolat terpenoid dengan berbagai eluen, setelah disemprot dengan pereaksi Libermann-Burchard didapatkan satu noda berwarna ungu yang membuktikan bahwa isolat yang diperoleh merupakan isolat murni.

\section{Analisis dengan FTIR}

Analisis FTIR menunjukkan spektra seperti pada gambar 4 .

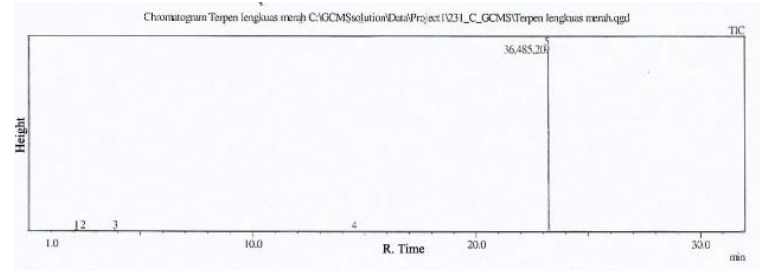

Gambar 4. Spektrum FTIR Isolat Terpenoid Rimpang Lengkuas Merah

Dari spektrogram di atas didapatkan serapan pada bilangan gelombang $1111 \mathrm{~cm}^{-1}, 1381 \mathrm{~cm}^{-1}, 1465 \mathrm{~cm}^{-1}, 1627$ $\mathrm{cm}^{-1}, 2854 \mathrm{~cm}^{-1}, 2924 \mathrm{~cm}^{-1}, 3441 \mathrm{~cm}^{-1}$. Serapan pada bilangan gelombang $1381 \mathrm{~cm}^{-1}$ dan $1465 \mathrm{~cm}^{-1}$ menunjukkan adanya vibrasi ikatan antara $\mathrm{C}-\mathrm{H}$ tekuk alifatik dari $\mathrm{CH}_{3}$ dan $\mathrm{C}-\mathrm{H}$ tekuk alifatik dari $\mathrm{CH}_{2}$. Pada bilangan gelombang $1111 \mathrm{~cm}^{-1}$ menunjukkan adanya vibrasi antara atom $\mathrm{C}$ dan $\mathrm{O}$ pada gugus alkohol. Sedangkan pada bilangan gelombang $2924 \mathrm{~cm}^{-1}$ dan $2854 \mathrm{~cm}^{-1}$ menunjukkan adanya ikatan $\mathrm{C}-\mathrm{H}$ ulur alifatik pada senyawa terpenoid. Pada bilangan gelombang 3441 $\mathrm{cm}^{-1}$ menunjukkan adanya vibrasi ikatan antara $\mathrm{O}$ dan $\mathrm{H}$ pada gugus alkohol [8].

Dari hasil uji Libermann-Burchard diketahui bahwa isolat didapatkan merupakan senyawa terpenoid. Sedangkan dari hasil spektra FTIR diketahui bahwa pada isolat yang dihasilkan terdapat gugus $\mathrm{CH}_{2}, \mathrm{CH}_{3}, \mathrm{C}=\mathrm{C}, \mathrm{C}-$ $\mathrm{O}$, dan $\mathrm{OH}$ sehingga dapat diketahui bahwa terpenoid yang didapatkan merupakan terpenoid alkohol. Hal ini sesuai dengan penelitian yang dilakukan oleh Rosyidah [9] bahwa jenis terpenoid yang ditemukan pada rimpang lengkuas merah merupakan jenis terpenoid alkohol.

\section{Analisis dengan GC-MS}

Hasil kromatogram GC isolat terpenoid rimpang lengkuas merah ditunjukkan seperti gambar 5 .

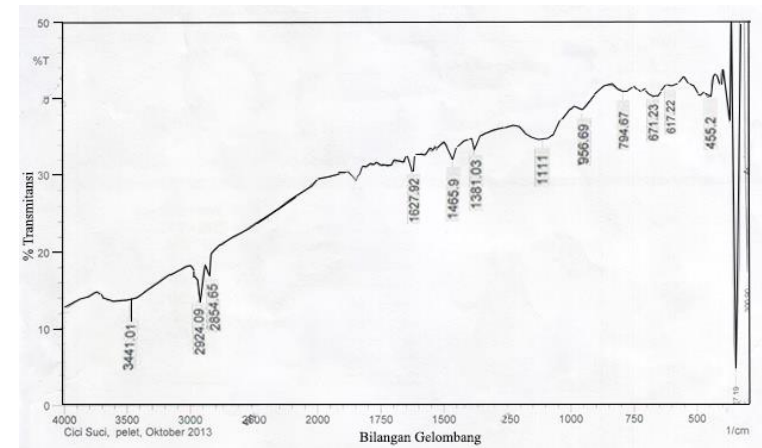

Gambar 5. Kromatogram GC Isolat Terpenoid Lengkuas Merah

Dari gambar kromatogram GC tersebut dapat diidentifikasi bahwa isolat terpenoid dari lengkuas merah memiliki kemurnian tinggi. Hal tersebut dibuktikan dengan hanya adanya 1 puncak dominan yang memiliki intensitas yang tinggi. Sehingga dengan kemurnian tinggi tersebut proses isolasi dari terpenoid yang dilakukan terhadap lengkuas merah (Alpinia 
purpurata) bisa dinyatakan berhasil. Senyawa tersebut memiliki waktu retensi 23,367 menit.

Dari hasil analisis menggunakan MS akan diketahui berat molekul yang dipunyai isolat terpenoid lengkuas merah. Berat molekul dan pola fragmentasi dari analisis MS dapat mengidentifikasi jenis senyawa dari isolat terpenoid tersebut. Analisis MS yang dihasilkan spektrogram seperti ditunjukkan pada gambar 6 .

(a)

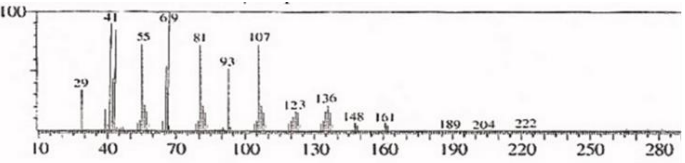

Hit\#1 Entry: 24123 Library: WILEY7.LIB

SI: 96 Formula:C15 H26 O CAS: 7212-44-4 MolWeight: 222 RetIndex: 0 CompoundName: 3,7,11-trimethyl-1,6,10-dodecatrien-3-ol\$s

(b)

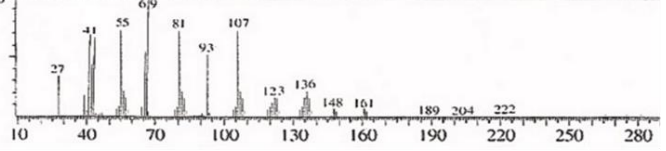

Gambar 6 (a) Spektra MS Senyawa Isolat Terpenoid Rimpang Lengkuas Merah dan (b) Spektra MS Refferensi Senyawa 3,7,11-trimetil-1,6,10-dodekatrien3-ol

Berat molekul yang dihasilkan dari analisis MS adalah $222 \mathrm{gram} / \mathrm{mol}$, diprediksikan senyawa isolat terpenoid berdasarkan spektra referensi MS adalah 3,7,11-trimetil-1,6,10-dodekatrien-3-ol dengan tingkat kemiripan $96 \%$.

Dari penelitian yang dilakukan Parwata dan Dewi [10] didapatkan senyawa terpenoid yang ada pada komponen minyak atsiri pada rimpang lengkuas merah antaralain senyawa 3,7,11-trimetil-1,6,10-dodekatrien30l. Sehingga dari kedua penelitian tersebut memperkuat dugaan bahwa terpenoid yang didapatkan dari rimpang lengkuas merah adalah 3,7,11-trimetil1,6,10-dodekatrien-3-ol.

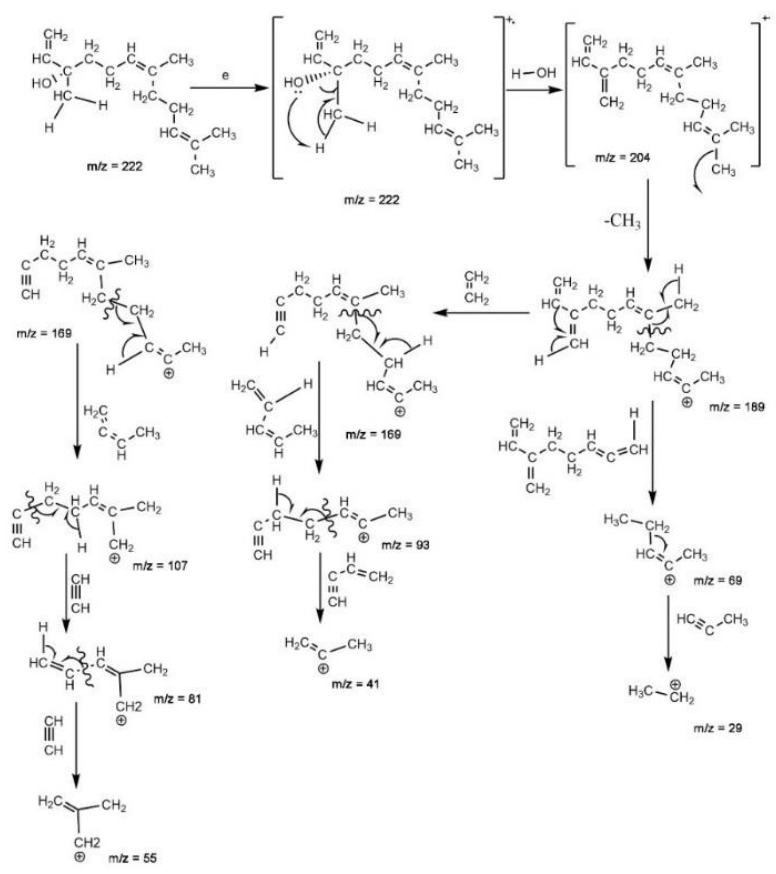

Gambar 7. Pola Fragmentasi Isolat Terpenoid
Kedua spektra tersebut mempunyai base puncak yang sama yaitu 69. Selain itu pola fragmentasi dari isolat terpenoid sesuai dengan senyawa 3,7,11-trimetil1,6,10-dodekatrien-3-ol yang keluar pada $(\mathrm{m} / \mathrm{z})$ : 222, 204, 189, 169, 107, 93, 81, 55, 41, dan 29. Pada spektra m/z 204 menunjukkan lepasnya senyawa $\mathrm{H}_{2} \mathrm{O}$ dari senyawa awal. Selanjutnya muncul m/z 189 yang menunjukkan lepasnya $\mathrm{CH}_{3}$. Senyawa dengan $\mathrm{m} / \mathrm{z} 69$ yang merupakan base puncak dari spektra MS dihasilkan dari pembentukan senyawa $\left(\mathrm{C}_{5} \mathrm{H}_{9}\right)^{+}$. Selain itu pada pola fragmentasi isolat terpenoid muncul $\mathrm{m} / \mathrm{z} 169$ akibat lepasnya senyawa $\mathrm{C}_{2} \mathrm{H}_{4}$ dari m/z 189. Dari m/z 169 menghasilkan senyawa $\mathrm{m} / \mathrm{z} 93$ akibat lepasnya $\mathrm{C}_{5} \mathrm{H}_{8}$ dan $\mathrm{m} / \mathrm{z} 107$ dari lepasnya $\mathrm{C}_{4} \mathrm{H}_{6}$. Dari m/z 107 menghasilkan fragmen dengan $\mathrm{m} / \mathrm{z} 81$ dan $\mathrm{m} / \mathrm{z} 55$ dengan lepasnya $\mathrm{C}_{2} \mathrm{H}_{2}$ dan $\mathrm{C}_{2} \mathrm{H}_{2}$ berturut-turut. Sedangkan $\mathrm{m} / \mathrm{z} 41$ didapat dari lepasnya senyawa $\mathrm{C}_{4} \mathrm{H}_{4}$ dari $\mathrm{m} / \mathrm{z}$ 93. Pola fragmentasi dari senyawa 3,7,11-trimetil-1,6,10dodekatrien-3-ol ditunjukkan seperti pada gambar 7 . Senyawa 3,7,11-trimetil-1,6,10-dodekatrien-3-ol merupakan terpenoid jenis alkohol dengan rumus molekul $\mathrm{C}_{15} \mathrm{H}_{26} \mathrm{O}$.

\section{Uji Antibakteri Isolat Terpenoid}

Uji antibakteri isolat terpenoid dilakukan terhadap bakteri Eschercia coli dan Salmonella typhy. Isolat terpenoid yang didapatkan sebanyak 0,04 gram kemudian dilarutkan ke dalam $4 \mathrm{~mL}$ aquades dengan ditambahkan 2 tetes DMSO. Penambahan DMSO berfungsi agar isolat terpenoid dapat larut sempurna dengan aquades selanjutnya diuji antibakteri menggunakan metode diffusi cakram terhadap bakteri Eschercia coli dan Salmonella typhy.

Jumlah koloninya diatur hingga sebanyak 0,1 MF atau setara dengan $1 \times 10^{7} \mathrm{CFU}$. JumLah koloni ini sesuai dengan penelitian yang dilakukan Kochuthressia dkk. [1]. Dari hasil pengujian antibakteri didapatkan hasil seperti pada gambar 8 .

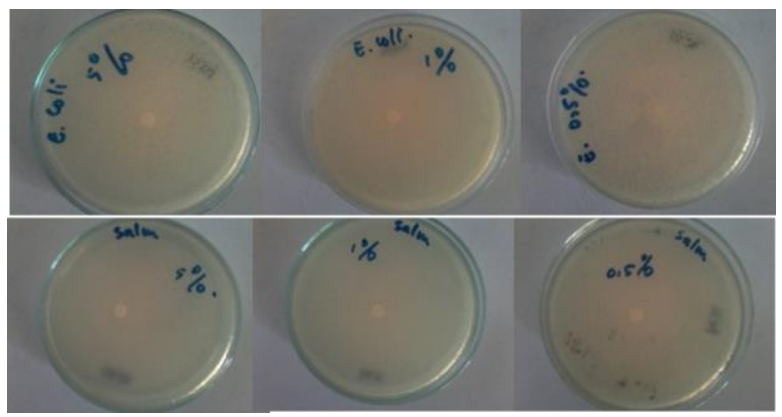

Gambar 8. Hasil Uji Antibakteri Isolat Terpenoid terhadap Eschercia coli dan Salmonella typhy

Dari hasil pengujian menggunakan metode diffusi cakram dapat dilihat dari gambar 8 bahwa tidak ada aktivitas antibakteri dari isolat terpenoid pada konsentrasi $5 \%, 1 \%$ dan $0,5 \%$. Hal ini ditandai dengan tidak adanya zona bening di sekeliling cakram atau zona hambatnya $0 \mathrm{~mm}$. Hal ini menunjukkan bahwa isolat terpenoid tersebut yaitu senyawa 3,7,11-trimetil-1,6,10dodekatrien-3-ol pada konsentrasi 0,5\%, 1\%, dan 5\% tidak memiliki aktivitas antibakteri. Hasil pengukuran 
zona hambat ini diukur tanpa menggunakan kontrol pisitif dan kontrol negatif.

\section{Kesimpulan}

Fraksi B berupa gel berwarna coklat kehitaman merupakan fraksi yang paling sitotoksik dengan nilai LC50 terkecil (7,862 ppm). Analisis menggunakan kromatografi gas-spektrometer massa (GC-MS) menunjukkan bahwa fraksi B terdapat 29 senyawa. Senyawa-senyawa sitotoksik ekstrak daun tempuyung yang memiliki indeks kemiripan dan kelimpahan besar yaitu dibutil ftalat, asam palmitat, 8,11,14 asam eikosatrienoat, dioktil adipat dan dioktil ftalat.

\section{Daftar Pustaka}

[1] KP Kochuthressia, S John Britto, MO Jaseentha, L Joelri Michael Raj, SR Senthilkumar, Antimicrobial efficacy of extracts from Alpinia purpurata (Vieill.) K. Schum. against human pathogenic bacteria and fungi, Agriculture and Biology Journal of North America, $\begin{array}{llll}1, & 6, & \text { (2010) } & 1249-1252\end{array}$ http://dx.doi.org/10.5251/abjna.2010.1.6.1249.1252

[2] Narayan Das Prajapathi, SS Purohit, Arun K Sharma, Tarun Kumar, A handbook of medicinal plants: A complete source book, Agrobios, India, 396, (2003)

[3] R Othman, H Ibrahim, Mustafa Ali Mohd, MR Mustafa, K Awang, Bioassay-guided isolation of a vasorelaxant active compound from Kaempferia galanga L, Phytomedicine, 13, 1, (2006) 61-66 http://dx.doi.org/10.1016/j.phymed.2004.07.004

[4] Justi C Jovitta, Sreenivasan Aswathi, S Suja, In-vitro antioxidant and phytochemical screening of ethanolic extract of Alpinia purpurata, International Journal of Pharmaceutical Sciences and Research, 3, 7, (2012) 2071

[5] I WG Gunawan, I GA Gede Bawa, NL Sutrisnayanti, Isolasi dan Identifikasi Senyawa Terpenoid yang Aktif Antibakteri pada Herba Meniran (Phyllanthus niruri Linn), (1907)

[6] Geanne KN Santos, Kamilla A Dutra, Rosângela A Barros, Claudio AG da Câmara, Diana D Lira, Norma B Gusmão, Daniela MAF Navarro, Essential oils from Alpinia purpurata (Zingiberaceae): chemical composition, oviposition deterrence, larvicidal and antibacterial activity, Industrial Crops and Products, 40, (2012) 254-260 http://dx.doi.org/10.1016/j.indcrop.2012.03.020

[7] Hasan R. H; Macabeo G, Investigation on antimicrobial activities of the plant Clerodendrum viscosum Vent, J. Innov. Dev. Strategy 6, 1, (2012) 6972

[8] Hardjono Sastrohamidjojo, Spektroskopi, Yogyakarta: Liberty, (1991)

[9] Kholifatu Rosyidah, Dua Senyawa Terpenoid Alkohol Dari Rimpang Lengkuas Merah, Skripsi, Universitas Lambung Mangkurat, Banjarbar, Kalimantan Selatan.

[10] I M Oka Adi Parwata, P Fanny Sastra Dewi, Isolasi dan uji aktivitas antibakteri minyak atsiri dari rimpang lengkuas (Alpinia galanga L.), (2012) 